\title{
АКТУАЛІЗАЦІЯ ПОНЯТТЯ «ЖИТТЕЗДАТНІСТЬ ЛЮДИНИ» ЯК КЛЮЧОВОЇ КАТЕГОРІЇ СУЧАСНОЇ ПСИХОЛОГІї
}

\author{
УдК: 316.6
}

\section{Ковальчук Анна Юріӥвна \\ Студентка Інституту післядипломної освіти Київ- ського національного університету імені Тараса Шевченка, м. Киів (Украӥна) \\ ORCID: https://orcid.org/0000-0002-8877-3360}

\begin{abstract}
Аннотация. Статтю присвячено розгляду сутності однієї з найбільш актуальної психологічної категорї - життєздатності, яку розуміємо як здатність людини управляти ресурсами власного здоров'я і соціально прийнятним способом використовувати для цуього сім 'ю, суспільство, культуру (за М. Унгаром); як системну якість особистості, щяо характеризує органічну єдність індивідуальних $і$ соцуіально-психологічних здібностей людини до реалізації ресурсного потенціалу, використання конструктивних стратегій поведінки в важких життєвих ситуаціях і в умовах сочіально-економічної депривації, щзо забезпечує повернення особистості на докризовий рівень функиіонування $i$ визначає посткризовий особистісний ріст (за $A$. Нестеровою). Психологічна категорія життєздатності має як споріднені з нею терміни, серед яких: 1) психічне здоров'я людини; 2) життєве самоздійснення; 3) опірність; 4) «почуття зв'язності»; 5) адаптація; 6) регуляиія; 7) феномен стійкості; так і неспоріднені, серед яких: 1) «віктимність»; 2) «психологічна безпорадність».
\end{abstract}

Ключевые слова: «життєздатність людини», психічне здоров'я людини, життєве самоздійснення, опірність, «почуття зв'язності», адаптація, регуляція, феномен стійкості, «віктимність», «психологічна безпорадність».

Постановка проблеми. На сучасному етапі розвитку наукознавства актуалізується проблема цінності людського життя у всіх іiі різноманітних контекстах, яка є предметом дослідження цілої низки наукових дисциплін і гуманітарних практик. Саме тому і дотепер відкритою залишається проблема життєздаmності, яка знайшла відображення в концепції людського капіталу - найважливішого інтегративного показника сучасної економічної та політичної державності, глобального стратегічного ресурсу добробуту будь-якої соціа- 
льної системи (див. праці І. Бурікової, М. Коновалової, М. Пушкіної та ін.). Поряд з такими концептами, як працездатність, здатність до інноваційної діяльності та навчання, життєздатність людини можна вважати базовою складовою людського капіталу, що вимагає не лише всебічного обліку в практиці управління, але і спеціальної уваги в теорії пізнання.

Попри те, що поняття «життєздатність» має численні споріднені поняттями зі схожими референтами, серед яких застосовуються такі категорії: почутmя зв'язності (англ. the sense of coherence) (A. Antonovsky, A. Dilani, J. Golembiewski), розростання (англ. thriving) (J. Iscovics, M. Seligman), невразливість (англ. invulnerability) (N. Garmezy), життєстійкість, когнітивна життестійкість (англ. hardiness, cognitive hardiness) (E. Florian, M. Mikulincer, O. Taubman), onipність (англ. selfresistance) (Ж. Іонеску), гнучкість, пластичність, резилентність (англ. resilience) (M. Bernard, U. Bronfenbrenner, D. Hellerstein, J. Kidd, G. Richardson), самоефективності (англ. self-efficiency) (А. Bandura) та ін. Як бачимо, концепт «життєздатність» тягне за собою шлейф неоднозначних, часом суперечливих асоціацій, заснованих на розбіжних думках про феноменологічну сутність релевантних концептів.

У зв'язку з цим, спробуємо розглянути психологічний статус поняття «життєздатність», іiі місце в структурі психічної організації людини.

\section{Аналіз останніх досліджень і публіка-}

цій. Сьогоденна загальна психологія характеризується наявність великих можливостей у контексті дослідження життєздатності людини, оскільки вона здатна окреслити системні й інваріантні складові іiі структури, розкрити фундаментальні закономірності і механізми реалізації. Так, аналіз теоретикометодологічної наукової літератури дав змогу виокремити положення, пов'язані $з$ поняттям «життєздатність»: положення філософської антропології про людину (М. Бахтіна, Н. Бердяєв, М. Мамардашвілі та ін.); теоретичні постулати позитивної психології, яка розкриває роль «чеснот» - вищих індивідуальнопсихологічних якостей людини в здійсненні ї̈ життя (M. Seligman та ін.); конщепиії життєвого шляху людини, ї̈ становлення у професійній діяльності, наукові уявлення про особливості психологічного онтогенезу $i$ завдань в nеріод зрілості (К. Абульханова, Ю. Поваренко, Е. Солдатова та ін.); система екзистениійно-гуманістичних і трансперсональних наукових уявлень про иілісність, унікальність, свободу, креативність, трансцендентальність й «індивідуацію» людини, тощуо (Л. Бінгсвангер, А. Маслоу, Г. Оллпорт, К. Юнг, J. Bugental та ін.); психологічні концепиії, тобто продуктивні ідеї про синергетичну, самоорганізуючу природу життєздатності, життестійкості, самоактуалізації й самореалізації особистос$m i$ (Д. Леонтьєв, А. Махнач, М. Bernard, S. Maddi, M. Neenan, G. Richardson, E. Werner та 
ін.).

Мета статті. Дане дослідження спрямовано на з'ясування сутності поняття «життєздатність людини» як ключової категорії сучасної психології.

Виклад основного матеріалу і результатів дослідження. На сучасному етапі розвитку психологічної науки загальноприйнятим вважається визначення поняття «життєздатність», сформульоване М. Унгаром: «життездатність - це здатність людини управляти ресурсами власного здоров'я i соціально прийнятним способом використовувати для цього сім'ю, суспільство, культуру» [17]. При цьому А. Махнач і А. Лактіонова дещо уточнили таке витлумачення: «життєздатність - це індивідуальна здатність людини керувати власними ресурсами: здоров'ям, емоційною, мотиваційновольовою, когнітивною сферами в контексті соціальних, культурних норм і середовищних умов» [11, с. 294]. На окрему увагу заслуговує позиція А. Нестерової, яка представила життєздатність як системну якість особистості, що характеризує органічну єдність індивідуальних і соціально-психологічних здібностей людини до реалізації ресурсного потенціалу, використання конструктивних стратегій поведінки в важких життєвих ситуаціях і в умовах соціально-економічної депривації, що забезпечує повернення особистості на докризовий рівень функціонування і визначає посткризовий особистісний ріст [12].
Звичайно, на сьогодні в психології простежується ціла низка понять, які за змістом є наближеними до поняття «життєздатність». Насамперед, життєздатність співвідноситься 3 проблемою потенцій. На думку В. Мясищева в психічному можна встановити дві категорії - потенційну і процесуальну, які не можуть існувати одне без одного, проте вони при цьому не $\epsilon$ тотожними. Б. Братусь також підкреслює найважливішу роль потенціалу людини як фактора особистісного розвитку. Він припускає, що людина є правдивою не в модусі наявності, а в модусі повинності, тобто поєднання полюсів сущого і належного, готівкового та можливого [4].

Д. Леонтьєв вводить поняття «особистісний потенціал», який розглядається як інтегральна характеристика рівня особистісної зрілості, в той час як головним феноменом особистісної зрілості і формою прояву особистісного потенціалу є феномен самодетермінації особистості. Поняття, що є близьким за змістом до особистісного потенціалу є поняття «життєтворчість», яке дослідник визначає як розширення світу, в результаті якого людина починає сприймати все під кутом зору вічності, під кутом зору моральних цінностей [8]. Іноді життєздатність розглядають як адаптаційну здатність у контексті гомеостатичного регулювання, підкреслюючи, що існування гомеостазу утримує життєзабезпечуючі функції організму в межах допустимих відхилень, незважаючи на різноманіття і неодно- 
значні зміни зовнішнього середовища. Як уважає С. Посохова, всі питання пристосування біологічних об'єктів до постійно змінюваних умов зводяться до стійкості. Адаптація розуміється як цілеспрямована системна реакція організму на тривалі і багаторазові, інтенсивні й екстенсивні впливу зовнішнього середовища, які призводять до порушення гомеостатичного балансу. Формування системної відповіді забезпечує людині екологічну рівновагу, можливість здійснення всіх видів соціальної діяльності і підтримки власної життєздатності [13].

Іноді життєздатність трактується як синонім психічного здоров'я і розглядається як передумова психічне здоров'я: «Психічне здоров'я людини інтерпретується як власна життєздатність людини, життєва сила, забезпечена повноцінним розвитком і функціонуванням психічного апарату. Життєздатність або вміння виживати, пристосовуватися і розвиватися в умовах, що змінюються, не завжди в сприятливих умовах $є$ передумовою психологічного здоров'я» $[15$, с. 70$]$.

Близьким до поняття «життєздатність» є категорія життєвого самоздійснення, яка надається як форма самоорганізації у процесі свого становлення і визначає інтенціональність руху і здатність до взаємодії зі світом для реалізації життєвих виборів [9].

У зарубіжній психології також використовується велика кількість термінів, які $€$ спорідненими 3 поняттям «життєздатність».
Дані про хронологію їх появи в тезаурусі психологічної науки $\epsilon$ досить суперечливими. Так, Ж. Іонеску говорить про таке явище, як onipнiсть (англ. resistance), стверджуючи, що вперше про нього говорилося в «Американському журналі з психіатрії» ще в 1942 р. В одній зі статей були описані результати діяльності британських соціальних працівників під час Другої світової війни, які помітили, що діти перед обличчям небезпечних для життя ситуацій проявляли дивну опірність. Аналізуючи сучасні уявлення про опірність, Ж. Іонеску стверджує, що цей феномен може розглядатися в трьох основних аспектах: 1) як здатність розвиватися нормально в психологічному плані, незважаючи на дестабілізуючі або травмуючі події, важкі умови існування, травматизм або здатність успішно адаптуватися до нещасть і лих, швидко відновлюватися після цих ситуацій; 2) як результат, що виявляється у відсутності психічних розладів під час і після ситуацій, здатних викликати такі розлади; 3) як процес, що включає взаємодію суб'єкта і середовища, що актуалізує середовищні і індивідуальні чинники захисту, які регулюють можливі ризики. Узагальнюючи уявлення про опірність, Ж. Іонеску приходить до висновку, що опірність є результатом динамічної рівноваги (балансу) між факторами ризику і факторами захисту, які визначаються індивідуальними якостями людини та особливостями зовнішнього середовища, що представляють певний ризик. Якщо фактори 
ризику врівноважуються факторами захисту, баланс зміщується в бік опору, якщо ж фактори ризику переходять допустиму межу, то точка рівноваги зміщується в бік уразливості, i людині буває складно пережити труднощі, які виникли [6].

У сучасній зарубіжній психології використовується ще низка понять, які є близькими за змістом до терміна «життєздатність». До їх числа дослідники відносять «почуття зв'язності» (англ. sense of coherence), яке було започатковане в надрах теорії салютогенезу А. Антоновського. Дослідник задався зовсім не простим питанням про джерела і походження здоров'я людини. Для того, щоб відповісти на це питання, він запропонував поняття «ресурси загального опору», які включали сукупність всіх факторів, які відповідають за подолання стресу. На думку автора, ресурси загального опору володіють магічною, імуностимулюючою дію, вони полегшують розуміння сенсу факторів стресу, яким ми змушені протистояти. Для визначення цієї дії А. Антоновський використовував складну категорію «сенс зв'язності», який співвідноситься з відчуттям стійкої і динамічної віри в таке: 1) стимули, які ми отримуємо з зовнішнього і внутрішнього середовища протягом всього свого життя, є структурними, передбачуваними, зрозумілими; 2) у людини є всі необхідні ресурси для реагування на вимоги цих стимулів; 3) вимоги стимулів завжди $є$ певним викликом [16].
Таким чином, «почуття зв'язності» характеризується трьома основними моментами: a) стимули зовнішнього і внутрішнього середовища є чіткими і зрозумілими; б) людина здатна управляти ситуацією, що формується цими стимулами; в) завдяки усвідомленню людиною сенсу подій, вони сприймаються як виклик, що вимагає прийняття і гідної відповіді, тому не відчуваються як непосильна ноша.

В англомовних джерелах для позначення явищ, які є подібними до життєздатності, використовуються також поняття «регуляція» (англ. adjustment) i «адаптація» (англ. adaptation).

Регуляція розглядається як поняття ширше, як стан гармонії між внутрішніми потребами і зовнішніми вимогами, а також як сукупність процесів, які використовуються для досягнення цього стану. Крім цього підкреслюється, що регуляція має бути відокремлене від адаптації за принципом віднесення до фізіології або біології.

Життєздатність часто розглядають у контексті опанування поведінкою (англ. coping), під яким розуміється індивідуальний спосіб взаємодії із ситуацією відповідно до їі власної логіки, значущістю в житті людини і їі психологічними можливостями [10]. Д. Хеллерштейн визначає життєздатність як ефективний «копінг», який реалізує функцію ослаблення хронічного стресу. При цьому сама життєздатність виступає як фундаментальна якість будь-якої здорової людини [18]. 
У межах когнітивних концепцій «копінг» використовується не лише для забезпечення і підтримки благополуччя людини, iii фізичного і психічного здоров'я, але і для задоволення потреби в соціальних контактах [25]. М. Зейдер говорить про ресурси опанування як специфічних особистісних характеристиках, які допомагають індивіду опанувати ситуацію стресу більш ефективно, переживати iii симптоми менш інтенсивно і швидше виходити з небезпечної ситуації. На думку автора, на «копінг-компетентність» і резистентність до стресу впливають «копінг-ресурси», до яких належать екстраверсія, психічне здоров'я, соціально-психологічні особливості сім'ї, сімейні традиції, згуртованість, міжособистісні відносини [там само].

Основна заслуга при вивченні проблеми опанування або «копінга» належить Р. Лазарус. Розроблена ним теорія стресу i «копінга» дозволила максимально чітко і конкретно уявити структуру процесу опанування, спрямованого на регулювання транзакцій між людиною і середовищем. У своїй теорії Р. Лазарус виходив, насамперед, із суб'єктивного переживання стресу і приділяв особливу увагу когнітивним процесам, розглядаючи стресори i способи подолання 3 ними 3 точки зору специфічних характеристик ситуації. У контексті транзакціональної когнітивної теорії «копінг» або опанування зі стресовою ситуацією розглядалися як діяльність особи з підтримки балансу між вимогами середовища і ресурсами, що задовольняють ці вимоги [20].

Одним 3 найбільш вивчених явищ, яке є спорідненим 3 поняттям «життєздатність», $є$ феномен стійкості (англ. hardiness). Категорія стійкості була введена в науковий обіг С. Мадді і колегами [21]. Стійкість передбачає визнання людиною своїх можливостей і прийняття реальності власної вразливості. Її розглядають як особливий патерн структури установки і навичок, який дозволяє перетворити власні зміни в реально здійсненні можливості, як ту базу, на основі якої, переробляються стресові впливи.

Стійкість - це інтегральна характеристику особистості, що зумовлює стійкість до стресів і складається 3: а) життєстійкого, тобто трансформаційного копінга; б) життєстійкого ставлення до оточуючих людей; в) життєстійких установок: залучення, контролю, прийняття ризику.

Трансформаційний копінг включає: а) сприйняття змін як гострих проблем, які очікують свого рішення; б) здійснення необхідних когнітивних і поведінкових дій для ефективного вирішення проблеми; в) витяг 3 досвіду вирішення проблеми максимальної користі в формі позитивних спостережень і цікавих, «мудрих» знахідок, що дозволяють людині рости і розвиватися в особистісному плані.

Життєстійке ставлення до інших людей - це прояв життєстійких установок у відносинах з людьми. Мова йде про те, що життєздатні люди в будь-яких умовах намагають- 
ся будувати міжособистісні відносини на основі взаємодопомоги, співробітництва і взаємної підтримки [7].

Залученість - це впевненість в тому, що навіть в неприємних, важких ситуаціях i стосунках краще бути в курсі подій, в контакті з оточуючими людьми, максимально присвячувати себе, свого часу, тому, що відбувається, активно в ньому брати участь. Контроль - це переконаність у тому, що людина завжди може вплинути на хід подій. Якщо ж ситуація принципово не піддається ніякому впливу, то висока установка контролю допоможе прийняти наявний стан речей, змінити своє ставлення до нього, переоцінити те, що відбувається [7]. Не дивно, що так і хочеться згадати безсмертні слова М. Аврелія: «якщо не можеш змінити обставини, зміни своє ставлення до них» [5].

Прийняття ризику - це віра в те, що стреси і зміни становлять невід'ємну, природну і необхідну частину життя, що будь-яка життєва ситуація - це цінний досвід, який допомагає розвиватися далі, все глибше осмислюючи власне розуміння буття [7].

C. К-Кобаса запропонувала термін «когнітивна життєстійкість» (англ. cognitive hardiness) для опису адаптивної поведінки індивідів, які під впливом сильного стресу виявляють високу стійкість до захворювань. Під життєстійкістю автор розуміє поєднання (букв. «пучок») певних властивостей, які виступають як ресурси протистояння стресовим життєвим подіям [19].

Категорія стійкості має особливе значення для уточнення понятійного поля терміна «життєздатність», оскільки вона є однією 3 найбільш розроблених релевантних категорій, що використовується в психологічній науці. Співвідношенню цих понять приділяється певна увага на сторінках психологічних праць. Йдеться про те, наприклад, що життєздатність (i близьке до нього поняття «життєтворчість») співвідносяться 3 авторською позицією С. Мадді і запропонованої ним моделлю узгодженості [21]. Підкреслюється, що термін «життєстійкість» використовується в контексті проблематики подолання стресу, означає наявність аттитюдів, що мотивують людину трансформувати і перетворювати стресогенні життєві події.

Насамперед, необхідно розпочати 3 аналізу співвідношення понять «життєздатність» і «стійкість», тобто розгляду ï лексичних значень. Поняття «життєздатність» розглядається в двох планах: 1) біологічному - той, що володіє здатністю бути живим, зберігати життя; 2) соціальному - той, що здатний існувати і розвиватися, пристосований до життя (життєздатність людини).

Саме слово «життєздатність» $є$ складною лексичної категорією, яка має два кореня: «життя» і «здатність».

Складені слова не дозволяють нехтувати жодним з компонентів і допускає лінгвісти- 
чну інверсію - здатність до життя, тому сенс слова буде неповним або значимо спотвориться, якщо один з коренів опускається. У зв'язку 3 цим, будь-яке психологічне витлумачення поняття «життєздатність» повинно враховувати: по-перше, зміст того, що таке людське життя, які їі суттєві ознаки; по-друге, що таке здібності як такі.

Дещо по-іншому необхідно звернути увагу на поняття стійкість (англ. hardiness). При перекладі з англійської мови воно означає зухвалість, відвагу, сміливість, хоробрість, витривалість, фортеця, стійкість [3, с. 374]. Ця лексична одиниця є односкладовою і операціональною. У той же час, вона $є$ менш конкретною, оскільки не зовсім зрозуміло, в якій сфеpi цю ознаку буде задіяно. Постає єдине питання: чи дійсно був доданий відповідний елемент для того, щоб наблизити іiі до життя? Мова йде про те, що українському читачеві більш відомим є варіант цієї категорії, запропонований Д. Леонтьєвим як «життєстійкість» (тобто «життєва стійкість», а не «стійкість» взагалі) [8, с. 17]. Аналогічно справа стосується і англомовного варіанта власне життєздатності, яким є «resilience» [3, с. 658]. Якщо життєздатність - це «гнучкість, пружність, еластичність», то де ж тут життя?

Таким чином, перша відмінність життездатності від життєстійкості полягає в такому. Психологічний термін «життєстійкість» асимільовано в українську мову шляхом калькування, що призвів до трансформації вихідного простого терміна (стійкість - від «hardiness») в багатоскладовий «життєстійкість». Ймовірно, це було викликано відсутністю необхідного поняття у психологічній науці і сприяло розширенню сфери його застосування: від проблематики подолання стресу до більш широкого життєвого контексту.

Поняття «життєздатність» не є прямим запозиченням з англійської мови, оскільки воно вже було введено в психологічну науку. Проте, іноді воно розглядається за типом прямого запозичення терміна «resilience» (укр. гнучкість, пружність, пластичність), що має не тотожний сенс. Внаслідок цього, втрачаються смислові навантаження «життя» i «здатність». Здається, що в даному випадку більш продуктивним було б використання калькованого варіанта «vital ability» (укр. життєва здатність), що вже використовується К. Абульхановою [1].

Необхідно визнати, що на сьогодні категорії «життєздатність» $\mathrm{i}$ «resilience» 3 термінологічної позиції перебувають в стадії стандартизації. Як результат, іноді виникає термінологічна плутанина. «Resilience» трактується, наприклад, як стійкість [8, с. 17].

Друга відмінність життєздатності від життєстійкості стосується функціональних характеристик. Тут виникають додаткові складнощі. Так, концепт «hardiness» спочатку було виокремлено в ході досліджень, які були присвячені пошуку психологічних чинників успішного подолання стресу і зниження (або 
навіть попередження) внутрішньої напруги [8]. Він розглядався як ресурс опірності в стресових умовах. Навіть самі автори теорії «hardiness» розширили сферу іï дії, підкреслюючи, що ця властивість забезпечує не лише мужність і мотиваційні потреби в перетворенні потенційних негараздів, що виникають у стресових обставинах, але і надає можливості для подальшого особистісного зростання» [22].

Проте «hardiness» продовжують вважати основною змінною стресостійкості, «що характеризує міру здатності особистості витримувати стресову ситуацію, зберігаючи внутрішню збалансованість і не знижуючи успішності діяльності» [8, с. 17]. У такому функціональному контексті досить часто розглядають i «resilience», яку витлумачують як індивідуальний спосіб подолання стресу і негараздів. Диференціюючи поняття «resilience» i «hardiness», перше характеризують як проблему, точніше проблемну галузь, а другу як конкретний варіант підходу до вирішення цієї проблеми, тобто іiі механізм. Іноді «resilience» розглядають як наукову категорію, що позначає ефективний копінг, що сприяє ослабленню хронічного стресу.

У психології формується традиція розширеного витлумачення функціональної ролі життєздатності, яка, ймовірно, була закладена ще Б. Ананьєвим. Він розумів життєздатнiсть як загальну здатність людини до ефективного функціонування, що співвідноситься 3 високим рівнем життєвих функцій (див. пра- цю Б. Ананьєва). Сучасні дослідники виділяють такі функціональні аспекти життєздатності, як соиіальна адаптація, саморегуляиія, механізм управління власними ресурсами (див. працю А. Лактіонова), сприяння ефективному опору труднощам $і$ депривуючим факторам, посткризове зростання (див. працю А. Нестерова).

Проведений аналіз дозволяє зробити висновок про те, що функціональні відмінності категорій «життездатність» i «життєстійкість»є досить «розмитими», хоча умовно можуть бути визначені сферою дії цих понять: ширшої в контексті різних життєвих труднощів і життя в цілому (життєздатність) i більш вузької - в контексті подолання стресу (життєстійкість).

Третя відмінність між аналізованими поняттями полягає в тому, яку позицію вони займають в загальній структурі психіки людини. Оскільки життєстійкість розглядається як система переконань про себе, світ, про відносини в світі [3], як «комплекс трьох аттитюдів» [22], можна припустити, що вона найбільше відповідає підструктурі спрямованості. Життєздатність є здатністю, тобто входить у підструктуру індивідуально-психологічних властивостей. У той же час, життєстійкість розглядають як «міру здатності особистості витримувати стресову ситуацію [...]» [8], а вивчення життєздатності як «використання поняття «здатність» для дослідження інших сфер психічної активності» [24]. Саме тому цю різницю важко вважати певною. 
Окрім цього, «hardiness» i «resilience» мають різні методологічні корені. Перше поняття було розроблено в екзистенціальних традиціях і засноване на погляді про те, що людина сама формує себе, визначає свої перспективи і реалізує життєвий досвід. Опорною методологічною змінною «hardiness» $є$ екзистенційна мужність - якість, що характеризує вибір невідомості як шлях до подальшого зростання. «Resilience» відрізняється від «hardiness» у методологічному плані тим, що спочатку іiі концептуальні корені пов'язані 3 теоріями соціального пізнання, 3 когнітивнобіхевіоральними моделями, у яких «resilience», найчастіше, операціоналізується через категорію адаптації. Разом з тим, поняття «життєстійкість» і «життєздатність» є дійсно спорідненими. Вони є інтегральними психологічними характеристиками людини, що входять до системи його позитивного, життєствердного потенціалу. Нещодавні дослідження засвідчують про те, що життєстійкість робить позитивний вплив не лише в стресових ситуаціях, а й в ситуаціях, звичних для людини. Вивчаючи прояви життєстійкості в експериментальній ситуації особистісного вибору, Д. Леонтьєв, Є. Рассказова прийшли до висновку, що роль життєстійкості не зводиться лише до функції буфера в ситуації стресу і припустили, що вона є однією з опорних змінних особистісного потенціалу [8].

Можемо стверджувати, що життєстійкість $\epsilon$ не лише опорною змінною життєздат- ності людини, але і найважливішою передумовою іiі наукового вивчення. Останні дослідження життєстійкості засвідчують про те, що вчені починають замислюватися про те, що буде $з$ людиною «після копінга», «після подолання стресу», в подальших, «посткризових» ситуаціях його майбутнього життя, і яка властивість людини найбільшою мірою відповідає за людське життя в цілому. Використання теоретично обгрунтованої і операціональної категорії «життєстійкість» може сприяти вирішенню низки методологічних і психодіагностичних завдань дослідження феномена життєздатності.

$$
\text { Науковий аналіз поняття }
$$
«життєздатність» передбачає розгляд не лише споріднених, але і полярних понять. До їх числа можна віднести поняття «віктимність», яким прийнято позначати сукупність властивостей людини, що сприяють дезадаптивному стилю реагування суб'єкта, що призводить до збитку для його фізичного або емоційнопсихічного здоров'я. Саме тому О. Андроннікова вводить у науковий обіг поняття віктімологічного потенціалу, що включає компоненти індивідуальної та групової віктимізації в конкретний історичний момент, процес віктимізації, віктимологічні стимуляцію, функціональні механізми співвідношення «жертва винуватець злочину» [2].

Ще одним поняттям, яке позначає феномен, протилежний життєздатності, можна вважати поняття «психологічна безпорад- 
ність», яка виступає в двох основних різновидах «вивчена безпорадність» і «особистісна безпорадність». У зарубіжній психології перші дослідження вивченої безпорадності проводилися в контексті біхевіористичного напряму в 60-х рр. ХХ ст. на тварин. У 70-х рр. XX ст. теорія вивченої безпорадності зазнала трансформації з позиції когнітивних уявлень. Було виокремлено низку симптомів вивченої безпорадності: пасивність, когнітивні дефіцити, емоційні дефіцити (печаль, тривога, ворожість), знижена сила інстинктивних потреб, комплекс нейрохімічних дефіцитів і підвищення сприйнятливості до хвороби [23].

Таким чином, помічаємо, що в структуpi психологічної безпорадності простежуються компоненти, які є біполярними складовими життєздатності людини: труднощі саморегуляції і адаптації, екстрапунітивність, невміння використовувати соціальну підтримку, низька толерантність до фрустраційних впливів, переважання песимізму над оптимізмом, недолік психічної рівноваги, занижена самооцінка, рівень самоповаги і домагань, висока тривожність, емоційна нестійкість. Антагоністичний характер безпорадності і життєздатності проявляється в переважанні різних видів атрибутивного стилю. Життездатні люди зазвичай демонструють оптимістичний стиль атрибуції, а найважливішою умовою виникнення безпорадності і іï показником $\epsilon$ наявність песимістичного стилю: схильність думати, що погані події є постійними, відбуваються в усіх сфе- pax життя, а хороші події є тимчасовими, ситуативними, менш масштабними [23].

Генетичний зв'язок життєздатності і безпорадності виражається ще в тому, що ці психологічні характеристики людини виявляються як реакції на особливі життєві події (стресогенні, психотравмуючі, екстремальні та ін.). Важкі життєві події провокують запуск у індивіда деякого адаптивного або долаючого труднощі поведінкового стереотипу [14]. Однак, у життєздатної людини і людини з низьким рівнем життєздатності ці стереотипи мають протилежний знак, тобто виражаються в різній спрямованості реагування психічних механізмів. У людини з симптомом безпорадності психологічна травма може стати причиною психопатології, як фізична травма через хворобу. Причому найбільш травмуючим виявляється не лише погана, але і хороша подія, якщо вона є дуже великим стресом для людини. Це пояснюється тим, що психологічне здоров'я в цілому залежить від здатності підтримувати рівновагу між внутрішнім світом і навколишнім середовищем. Життєздатна людина відрізняється від безпорадної тим, що вона може підтримувати психічну рівновагу незалежно від модальності й інтенсивності життевої події або низку звичних, повсякденних, слабо забарвлених емоційно, «набридливих» подій.

Незважаючи на те, що в розробленій Д. Цицероном концепції феномен життєздатності не було проаналізовано в аспекті зв'язку з без- 
порадністю, було отримано емпіричне підтвердження про наявність зворотної залежності безпорадності і життєстійкості. Припускаємо, що подібна взаємозалежність характерна і для континууму «життєздатність - безпорадність». Правомірність виокремлення такого континууму визначається концептуальним підходом до безпорадності з тієї позиції, з якої вона розглядається як якість суб'єкта, що включає єдність специфічних особистісних особливостей, що виникають як результат взаємодії внутрішніх умов з зовнішніми, і визначальний низький рівень суб'єктності [...] [14].

У такий спосіб, виражена безпорадність характеризується зниженою або низькою суб'єктністю, яка блокує здатності до перетворення дійсності, до управління життєвими подіями, до постановки цілей і їх досягнення, до подолання різного роду труднощів і негараздів. Відповідно, особливе місце повинно належати порушенню цілісності людини, яка виражена в такій нерівномірності розвитку іiі особистісних і суб'єктних якостей, яка є значною для зниження ефективності діяльності і формування несприятливого паттерна поведінкових і соціально-психологічних характеристик. Життєздатність як біполярна якість передбачає збереження цієї цілісності, тобто таке поєднання особистісних і суб'єктних властивостей, яке забезпечує успішність діяльності і формування певного позитивного симптомокомплексу діяльнісних, поведінкових і соціально-психологічних проявів.
Висновки дослідження. Як висновок, можемо констатувати, що життєздатність як психологічна категорія має два ключових витлумачення: 1) як індивідуальна здатність людини керувати власними ресурсами: здоров'ям, емоційною, мотиваційно-вольовою, когнітивною сферами в контексті соціальних, культурних норм і середовищних умов (А. Махнач i А. Лактіонова); 2) як системну якість особистості, що характеризує органічну єдність індивідуальних і соціальнопсихологічних здібностей людини до реалізації ресурсного потенціалу, використання конструктивних стратегій поведінки в важких життєвих ситуаціях і в умовах соціальноекономічної депривації, що забезпечує повернення особистості на докризовий рівень функціонування і визначає посткризовий особистісний ріст (А. Нестерова).

При цьому термінологічне поле поняття «життєздатність» містить як споріднені поняття, серед яких психічне здоров 'я, життєве самоздійснення, опірність, «почуття зв'язності», «регуляція» $i$ «адаптація», феномен стійкості, так і неспоріднених, серед яких «віктимність», «психологічна безпораднiсть», яка виступає в двох основних різновидах «вивчена безпорадність» і «особистісна безпорадність».

\section{Перспективи подальших досліджень} вбачаємо у тому, що зазначені визначенні можуть бути розглянути з позиції інших, суміжних з психологічною наукою, дисциплін. 


\section{Перелік використаних джерел:}

1. Абульханова К. А. Сознание как жизненная способность личности / К. А. Абульханова // Психол. журн. 2009. - T. 30. - № 1. - С. 32-43.

2. Андроникова О. О. Психологические факторы возникновения виктимного поведения подростков: дис. ... канд. психол. наук / О. О. Андроникова. - Новосибирск, 2005. -213 c.

3. Большой современный англо-русский словарь / Г. П. Шалаева. - М., 2005. - 847 с.

4. Братусь Б. С. Аномалии личности / Б. С. Братусь. M., 1988. - $301 \mathrm{c}$.

5. Жемчужина мысли. Обстоятельства [Электронный pecypc]. - Режим доступа: http://www.inpearls.ru/pearls/ tag/id/1752/value/obstoyatelstva.

6. Ионеску Ж. К. Оценка сопротивляемости: совокупность факторов риска и защиты и необходимость их культурной адаптации / Ж. К. Ионеску // Травматизм, психологическая безопасность, сопротивляемость и культура: материалы международной конференции / под ред. В. В. Латюшина. - Челябинск, 2007. - Ч. 1. - С. 65-69.

7. Концепция жизнестойкости [Электронный ресурс]. Режим доступа: http:/kstera.ru/texts/hardiness/ index.html.

8. Леонтьев Д. А. Духовность, саморегуляция и ценности / Д. А. Леонтьев // Гуманитарные проблемы современной психологии. Известия Таганрогского государственного радиотехнического университета. - 2005. № 7. - С. 16-21.

9. Логинова И. О. Жизненное самоосуществление человека: системно-антропологический контекст: автореф. дис. ... д-ра психол. наук / И. О. Логинова. - Томск, 2010. -42 c.

10. Мазилов В. А. Психология на пороге XXI века: методологические проблемы / В. А. Мазилов. - Ярославль, 2001. - 112 с.

11. Махнач А. В. Международная конференция по проблемам жизнеспособности детей и подростков / А. В.
Махнач // Психол. журн. - 2006. - Т. 27. - № 2. - С. 131 $-132$.

12. Нестерова А. А. Социально-психологический подход к изучению жизнеспособности личности, находящейся в трудной жизненной ситуации / А. А. Нестерова. - М., 2011. - 243 с.

13. Посохова С. Т. Психология адаптирующейся личности: субъектный подход: дис. ... д-ра психол. наук / С. Т. Посохова. - СПб., 2001. - 393 с.

14. Цицерон М. Об обязанностях / М. Цицерон. - М., 1993. - $161 \mathrm{c}$.

15. Эрлих С. Н. Здоровые потребности и потребность в здоровье / С. Н. Эрлих // Валеология человека. Здоровье - любовь - красота: в 3 т. / под ред. В. П. Петленко. - СПб., 1996. - Т. 1. - С. 86-95.

16. Band E. How to feel better when it feels bad: Children's perspectives on coping with everyday stress / E. Band, J. Weisz // Developmental Psychology. - 1988. - V. 24. - P. 247-253.

17.Havigherst R. Developmental tasks and education / R. Havigherst. - New York, 1972. - P. 34-45.

18. Hellerstein D. How can I become resilient [Electronic Resource] / D. Hellerstein // Heal your brain. - Mode of Access: http:/www.psychologytoday.com/blog/heal-yourbrain/201108/ how-can-I-become-resilient.

19. K-Kobasa S. Stressful life events personality and health: an inquiry into hardiness / S. K-Kobasa // Journal of Personality and Social Psychology. - 1979. - No. 37. - P. 5 -11 .

20. Lazarus R. Psychological stress and the coping process / R. Lazarus. - New York, 1966. - 166 p.

21. Maddi S. Hardiness and mental health / S. Maddi, D. Khoshaba // Journal of Personality Assessment. - 1985. V. 63. - No. 2. - P. 265-274.

22. Mahon R. Career counseling: constructivist approaches / R. Mahon \& G. Patton. - London, 2006. - 360 p.

23. Sinclair V. The development and psychometric evaluation of the Brief Resilient Coping Scale / V. Sinclair \& K. Wallston // Assessment. - No. 11 (1). - P. 94-101.

24.Werner E. Risk, resilience and recovery perspectives 
from the Kauai longitudinal study / E. Werner // Development and psychopathology. - V. 5. - P. 81-85.

25. Zeider M. How high school and college students cope with test situations / M. Zeider // British Journal of Educational Psychology. - 1996. - V. 66. - P. 115-128.

\section{References (Transliterated):}

1.Abul'khanova K. A. Soznaniye kak zhiznennaya sposobnost' lichnosti / K. A. Abul'khanova // Psikhol. zhurn. 2009. - T. 30. - № 1. - S. 32-43.

2.Andronikova O. O. Psikhologicheskiye faktory vozniknoveniya viktimnogo povedeniya podrostkov: dis. ... kand. psikhol. nauk / O. O. Andronikova. - Novosibirsk, 2005. - $213 \mathrm{~s}$.

3.Bol'shoy sovremennyy anglo-russkiy slovar' / G. P. Shalayeva. - M., 2005. - 847 s.

4.Bratus' B. S. Anomalii lichnosti / B. S. Bratus'. - M., 1988. $-301 \mathrm{~s}$.

5.Zhemchuzhina mysli. Obstoyatel'stva [Elektronnyy resurs]. - Rezhim dostupa: http://www.inpearls.ru/pearls/ tag/id/1752/value/obstoyatelstva.

6.Ionesku Zh. K. Otsenka soprotivlyayemosti: sovokupnost' faktorov riska i zashchity i neobkhodimost' ikh kul'turnoy adaptatsii / ZH. K. Ionesku // Travmatizm, psikhologicheskaya bezopasnost', soprotivlyayemost' i kul'tura: materialy mezhdunarodnoy konferentsii / pod red. V. V. Latyushina. - Chelyabinsk, 2007. - CH. 1. - S. 65-69.

7.Kontseptsiya zhiznestoykosti [Elektronnyy resurs]. Rezhim dostupa: http://kstera.ru/texts/hardiness/ index.html.

8.Leont'yev D. A. Dukhovnost', samoregulyatsiya i tsennosti / D. A. Leont'yev // Gumanitarnyye problemy sovremennoy psikhologii. Izvestiya Taganrogskogo gosudarstvennogo radiotekhnicheskogo universiteta. - 2005. - № 7. - S. 16-21.

9.Loginova I. O. Zhiznennoye samoosushchestvleniye cheloveka: sistemno-antropologicheskiy kontekst: avtoref. dis. ... d-ra psikhol. nauk / I. O. Loginova. - Tomsk, 2010. - 42 s.
10.Mazilov V. A. Psikhologiya na poroge XXI veka: metodologicheskiye problemy / V. A. Mazilov. - Yaroslavl', 2001. - $112 \mathrm{~s}$.

11. Makhnach A. V. Mezhdunarodnaya konferentsiya po problemam zhiznesposobnosti detey i podrostkov / A. V. Makhnach // Psikhol. zhurn. - 2006. - T. 27. - № 2. - S. 131-132.

12.Nesterova A. A. Sotsial'no-psikhologicheskiy podkhod k izucheniyu zhiznesposobnosti lichnosti, nakhodyashcheysya v trudnoy zhiznennoy situatsii / A. A. Nesterova. - M., 2011. - $243 \mathrm{~s}$.

13.Posokhova S. T. Psikhologiya adaptiruyushcheysya lichnosti: sub"yektnyy podkhod: dis. ... d-ra psikhol. nauk / S. T. Posokhova. - SPb., 2001. - 393 s.

14.Tsitseron M. Ob obyazannostyakh / M. Tsitseron. - M., 1993. - $161 \mathrm{~s}$.

15.Erlikh S. N. Zdorovyye potrebnosti i potrebnost' v zdorov'ye / S. N. Erlikh // Valeologiya cheloveka. Zdorov'ye lyubov' - krasota: v 3 t. / pod red. V. P. Petlenko. - SPb., 1996. - T. 1. - S. 86-95.

16.Band E. How to feel better when it feels bad: Children's perspectives on coping with everyday stress / E. Band, J. Weisz // Developmental Psychology. - 1988. - V. 24. - P. 247-253.

17.Havigherst R. Developmental tasks and education / R. Havigherst. - New York, 1972. - P. 34-45.

18. Hellerstein D. How can I become resilient [Electronic Resource] / D. Hellerstein // Heal your brain. - Mode of Access: http:/www.psychologytoday.com/blog/heal-yourbrain/201108/ how-can-I-become-resilient.

19.K-Kobasa S. Stressful life events personality and health: an inquiry into hardiness / S. K-Kobasa // Journal of Personality and Social Psychology. - 1979. - No. 37. - P. 511.

20.Lazarus R. Psychological stress and the coping process / R. Lazarus. - New York, 1966. - 166 p.

21.Maddi S. Hardiness and mental health / S. Maddi, D. Khoshaba // Journal of Personality Assessment. - 1985. V. 63. - No. 2. - P. 265-274.

22.Mahon R. Career counseling: constructivist approaches / 
R. Mahon \& G. Patton. - London, 2006. - 360 p.

23.Sinclair V. The development and psychometric evaluation of the Brief Resilient Coping Scale / V. Sinclair \& K. Wallston // Assessment. - No. 11 (1). - P. 94-101.

24.Werner E. Risk, resilience and recovery perspectives from the Kauai longitudinal study / E. Werner // Development and psychopathology. - V. 5. - P. 81-85.

25.Zeider M. How high school and college students cope with test situations / M. Zeider // British Journal of Educational Psychology. - 1996. - V. 66. - P. 115-128.

\section{Kovalchuk Anna}

Student of the Institute of Post-Graduate Education of Taras Shevchenko National University of Kyiv, Kyiv (Ukraine)

\section{ACTUALIZATION OF THE NOTION OF «HUMAN VIABILITY» AS A KEY CATEGORY OF MODERN PSYCHOLOGY}

\section{ABSTRACT}

The article deals with the consideration of the essence of viability, one of the most relevant psychological category. It is understood as the ability of a person to manage the resources of his / her own health and the socially acceptable way to use for this family, society, culture (according to M. Ungaro); as a systemic quality of a person characterising the organic unity of an individual's human and sociopsychological abilities to realise the resource potential, using constructive behavioural strategies in difficult life situations and in conditions of socioeconomic deprivation, which ensures that the individual returns to the pre-crisis level of functioning and determines post-crisis personal growth (according to A. Nesterova).

The psychological category of vitality has terms related to it, among which are: 1) mental health of a person is a person's own vitality, life force, which is ensured by the full development and functioning of the mental apparatus; 2) life self-realization is a form of self-organisation in the process of its formation, which determines the intentionality of movement and the ability to interact with the world for the realisation of life choices; 3) sustainability is the result of dynamic equilibrium (balance) between risk factors and protection factors, which are determined by individual human qualities and features of the external environment, and also represent a certain risk; 4) "feeling of connectedness" is characterised by three main points: a) the stimuli of the external and internal environment are clear and understandable; b) a person is able to control the situation, which is formed by these incentives; c) due to the human awareness of the meaning of events, they are perceived as a challenge, requiring acceptance and a decent response, and therefore are not felt as an unbearable burden; 5) adaptation is a targeted systemic reaction of the body to longterm and multiple, intense and extensive environmental effects that lead to disruption of the homeostatic balance; 6) regulation is the state of harmony between internal needs and external requirements, as well as a set of processes that are used to achieve this state; 7) stability phenomenon is the special pattern of the structure of the installation and skills, which allows you to turn 
your own changes into realistically realised opportunities, such as the basis on which stress effects are processed.

The notion of "vitality" has the following unrelated terms: 1) "victimhood" is a set of human properties that contribute to the maladaptive style of response of the subject, which leads to damage to his / her physical or emotional-mental health; 2) "psychological helplessness", which appears in two main varieties of "learned helplessness" and "personal helplessness".

Key terms: "human vitality", human mental health, life self-realization, stability, "feeling of connectedness", adaptation, regulation, stability phenomenon, "victimhood", "psychological helplessness".

\section{Ковальчук Анна Юрьевна}

Студентка Института последипломного образования Киевского национального университета имени Тараса Шевченко, г. Киев (Украина)

\section{АКТУАЛИЗАЦИЯ ПОНЯТИЯ «ЖИЗНЕСПОСОБНОСТЬ ЧЕЛОВЕКА» КАК КЛЮЧЕВОЙ КАТЕГОРИЕЙ СОВРЕМЕННОЙ ПСИХОЛОГИИ}

Аннотация. Статья посвящена рассмотрению сущности одной из наиболее актуальной психологической категории - жизнеспособности, которую понимаем как способность человека управлять ресурсами собственного здоровья и социально приемлемым способом использовать для этого семью, общество, культуру (по М. Унгаро); как системное качество личности, характеризующее органи- ческое единство индивидуальных и социально -психологических способностей человека к реализации ресурсного потенциала, использование конструктивных стратегий поведения в трудных жизненных ситуациях и в условиях социально-экономической депривации, которая обеспечивает возврат личности на докризисный уровень функционирования и определяет посткризисный личностный рост (по А. Нестеровой).

Психологическая категория жизнеспособности имеет смежные с ней термины, среди которых: 1) психическое здоровье человека - собственная жизнеспособность человека, жизненная сила, которая обеспечена полноценным развитием и функционированием психического аппарата; 2) жизненная самореализация - форма самоорганизации в процессе своего становления, которая определяет интенциональность движения и способность к взаимодействию с миром для реализации жизненных выборов; 3) устойчивость - результат динамического равновесия (баланса) между факторами риска и факторами защиты, которые определяются индивидуальными качествами человека и особенностями внешней среды, а также ж представляют определенный риск; 4) «чувство связности» характеризуется тремя основными моментами: а) стимулы внешней и внутренней среды являются четкими и понятными; б) человек способен управлять ситуацией, которая формируется этими стимулами; в) благодаря осознанию челове- 
ком смысла событий, они воспринимаются как вызов, требующий принятия и достойного ответа, поэтому не ощущаются как непосильная ноша; 5) адаптация - целенаправленная системная реакция организма на длительные и многократные, интенсивные и экстенсивные влияния внешней среды, которые приводят к нарушению гомеостатического баланса; 6) регуляция - состояние гармонии между внутренними потребностями и внешними требованиями, а также как совокупность процессов, которые используются для достижения этого состояния; 7) феномен устойчивости - особый паттерн структуры установки и навыков, который позволяет превратить собственные изменения в реально осуществленные возможности, как ту базу, на основе которой, перерабатываются стрессовые воздействия.

Среди неродственных с понятием «жизнеспособность» следует считать: 1) «виктимность» - совокупность свойств человека, которые способствуют дезадаптивному стиля реагирования субъекта, что приводит к ущербу для его физического или эмоционально-психического здоровья;

«психологическая беспомощность», которая выступает в двух основных разновидностях «выученная беспомощность» и «личностная беспомощность».

Ключевые слова: «жизнеспособность человека», психическое здоровье человека, жизненная самореализация, устойчивость, «чувство связности», адаптация, регуляция, феномен устойчивости, «виктимность», «психологическая беспомощность».
Дата отримання статті: 21.02.2019 Дата рекомендації до друку: 27.03.2019 Дата оприлюднення: 17.04.2019 